\title{
Karakteristik Penderita Tuberculosis Multidrug Resistant (TB MDR) di Sulawesi Tenggara Tahun 2014-2017
}

\author{
${ }^{1}$ Zida Maulina Aini, ${ }^{2}$ Nur Martina Rufia \\ ${ }^{1}$ Fakultas Kedokteran Universitas Halu Oleo \\ ${ }^{2}$ Program Studi Pendidikan Dokter \\ Email: zidamaulina@gmail.com
}

\begin{abstract}
Background:MDR TB is one type of bacterial tuberculosis resistance to first-line anti-TB drugs, Isoniazid and Rifampicin. Data from the Provincial Health Office of Southeast Sulawesi cases of MDR TB increase every year that is in 2014 there are 7 patients with MDR TB, 2015 there are 8 patients with MDR TB, 2016 there are 23 patients with MDR TB, and in 2017 there are 28 patients with MDR TB. The purpose of this study is to explain the characteristics of patients with MDR TB in Southeast Sulawesi in 2014-2017. Research Purpose: This study is to explain the characteristics of patients with MDR TB in Southeast Sulawesi in 2014-2017. Research Method: The location of this study was in the Provincial Health Office of Southeast Sulawesi and Bahteramas General Hospital of Southeast Sulawesi Province with study population included all patients diagnosed with MDR TB in Southeast Sulawesi Province 2014-2017. The research data is processed to know the number and percentage of each characteristic of MDR TB patients in Southeast Sulawesi 2014-2017. Research result: The conclusion of the result of the study is characteristic of MDR TB patient in Southeast Sulawesi 2014-2017 dominated by age 15-55 years old, male gender, entrepreneur job, case of drop out treatment, examination of chest X-ray in the form of infiltrate and cavity, sputum smear examination (+1), the type of Rifampicin resistance, and is still temporarily treated.
\end{abstract}

Keyword: MDR TB, age, sex, occupation, medical history, investigation, type of resistance and treatment outcome.

\section{PENDAHULUAN}

TB resisten obat adalah penyakit TB yang disebabkan oleh kuman Mycobacterium tuberculosis yang telah mengalami kekebalan terhadap OAT. Salah satu TB resisten obat yang saat ini menjadi perhatian adalah TB MDR (Tuberculosis Multidrug Resistant). TB MDR adalah salah satu jenis resistensi bakteri tuberkulosis terhadap minimal dua obat anti TB lini pertama, yaitu Isoniazid dan Rifampisin yang merupakan dua obat TB yang paling efektif pada pengobatan TB yang diterapkan pada strategi Directly Observed Therapy Short-Course (DOTS). TB khususnya TB MDR (Tuberculosis Multidrug Resistant) menjadi masalah kesehatan yang harus segera diatasi, karena insidennya yang terus meningkat setiap tahunnya dan berdampak pada meningkatnya angka kejadian TB XDR
(Extensively Resistant Tuberculosis)

(Kementrian kesehatan RI, 2014).

Berdasarkan data WHO memperkirakan terdapat 480.000 kasus TB MDR di seluruh dunia, sedangkan kematian akibat TB MDR diperkirakan 250.000 kasus pada tahun 2015. World Health Organization (WHO) dalam Global Tuberculosis Report 2015 melaporkan bahwa Indonesia termasuk salah satu negara dari 27 negara lainnya di dunia dengan kasus TB MDR yang cukup banyak yaitu terdapat 6800 kasus baru TB MDR setiap tahunnya. Diperkirakan 1.9\% dari kasus TB baru dan 12\% dari kasus TB pengobatan ulang. Berdasarkan Annual Report 2017, Indonesia menempati posisi ke dua kasus TB MDR tertinggi di Asia Tenggara setelah India (WHO, 2016).

Angka kejadian TB MDR di Indonesia setiap tahun mengalami 
peningkatan. Pada tahun 2012 di Indonesia terdapat 696 kasus TB MDR, tahun 2013 meningkat menjadi 1.094 kasus, kemudian tahun 2014 menjadi 1.752 kasus dan tahun 2015 di Indonesia terdapat 1.860 kasus terkonfirmasi TB MDR, 15.380 kasus terduga TB MDR dan 1.566 kasus telah diobati (Kementrian Kesehatan RI, 2016).

Data dari Dinas kesehatan provinsi Sulawesi Tenggara menyatakan kasus TB MDR terjadi peningkatan setiap tahun yaitu pada tahun 2014 terdapat 7 penderita TB MDR, tahun 2015 terdapat 8 penderita TB MDR, tahun 2016 terdapat 23 penderita TB MDR, dan tahun 2017 terdapat 28 penderita TB MDR (Profil Dinkes Prov. Sultra, 2016). TB MDR menjadi hambatan dan masalah utama dalam program pencegahan dan pemberantasan TB dunia karena penanganan TB MDR masih rendah. Salah satu alasan masih rendahnya cakupan pengobatan TB MDR adalah ketidakpatuhan pasien pada saat menjalani pengobatan TB yang menyebabkan pasien penderita TB di Indonesia menjadi TB MDR. Hal ini dapat disebabkan oleh beberapa faktor yaitu faktor penyedia layanan kesehatan, pasien dan obat. Faktor penyedia layanan kesehatan dapat berupa diagnosa yang tidak tepat, tidak mengikuti paduan yang tersedia, dosis, jenis, jumlah dan jangka waktu pengobatan yang tidak tepat, dan penyuluhan yang tidak adekuat (Kementrian Kesehatan RI, 2011).

Penularan

Mycobacterium tuberculosis yang telah mengalami resistensi obat akan menciptakan kasus baru. Penderita TB yang mengalami resistensi primer yaitu resistensi pada pasien yang tidak pernah mendapat OAT sebelumnya atau sudah pernah mendapat pengobatan tetapi kurang dari 1 bulan, akan mengarah pada peningkatan kasus multidrug resistant. Penyebaran TB MDR telah meningkat karena lemahnya pengendalian TB, kurangnya sumber dana dan isolasi yang tidak adekuat dan keterlambatan dalam menegakkan diagnosis suatu TB MDR (Sihombing, 2012).

\section{METODE PENELITIAN}

Penelitian ini merupakan penelitian deskriptif untuk mengetahui karakteristik penderita TB MDR di Provinsi Sulawesi Tenggara tahun 2014-2017 melalui rekam medik sebagai data penelitian. Penelitian ini dilaksanakan pada bulan JanuariFebruari 2018 di Dinas Kesehatan Provinsi Sulawesi Tenggara dan RSU Bahteramas Provinsi Sulawesi Tenggara. Sampel dalam penelitian ini adalah seluruh penderita TB MDR di Provinsi Sulawesi Tenggara tahun 2014-2017 dengan metode pengambilan sampel adalah total sampling. Dalam penelitian ini digunakan data sekunder yang diperoleh dari data Dinas Kesehatan Provinsi Sulawesi Tenggara dan data rekam medik di RSU Bahteramas Provinsi Sulawesi Tenggara. Data yang diperoleh akan diolah dengan menggunakan program komputer untuk mengetahui jumlah dan persentase masingmasing karakteristik penderita TB MDR di Sulawesi Tenggara tahun 2014-2017.

\section{HASIL PENELITIAN}

Penelitian dilaksanakan di Dinas Kesehatan Provinsi Sulawesi Tenggara dan RSU Bahteramas Provinsi Sulawesi Tenggara. Sampel dalam penelitian ini adalah seluruh penderita TB MDR di Provinsi Sulawesi Tenggara tahun 20142017 dengan metode pengambilan sampel adalah total sampling. Jumlah sampel yang diteliti pada penelitian ini adalah 40 
sampel. Penelitian ini menggunakan data sekunder yang diperoleh dari data Dinas Kesehatan Provinsi Sulawesi Tenggara dan data rekam medik di RSU Bahteramas Provinsi Sulawesi Tenggara untuk mengetahui karakteristik penderita TB MDR di Provinsi Sulawesi Tenggara tahun 2014-2017.

Berdasarkan Tabel 1, dapat diketahui bahwa kelompok usia terbanyak pada penderita Tuberculosis Multidrug Resistant (TB MDR) adalah pada usia produktif yaitu kelompok usia 15-55 tahun yang berjumlah 34 orang (85\%) sedangkan usia $>56$ tahun berjumlah 6 orang (15\%).

Berdasarkan Tabel 2, dapat diketahui bahwa pada penderita Tuberculosis Multidrug Resistant (TB MDR) lebih banyak laki-laki dibandingkan perempuan. Laki-laki berjumlah 28 orang $(70 \%)$ dan perempuan berjumlah 12 orang (30\%).

Berdasarkan Tabel 3, dapat diketahui bahwa pada penderita Tuberculosis Multidrug Resistant (TB
MDR) banyak yang bekerja yaitu bekerja sebagai wiraswasta berjumlah 11 orang (27,5\%), pegawai (PNS) berjumlah 4 orang $(10 \%)$, dan petani berjumlah 8 orang $(20 \%)$. Penderita yang tidak bekerja terdiri dari ibu rumah tangga berjumlah 6 orang $(15 \%)$, pelajar 3 orang $(7,5 \%)$ dan pengangguran berjumlah 8 orang $(20 \%)$.

Tabel 1. Distribusi jumlah dan persentase karakteristik penderita Tuberculosis Multidrug Resistant (TB MDR) di Sulawesi Tenggara tahun 20142017 berdasarkan usia

\begin{tabular}{ccc}
\hline Usia & Jumlah & Persentase (\%) \\
\hline $15-55$ tahun & 34 & 85 \\
$>56$ tahun & 6 & 15 \\
\hline Total & $\mathbf{4 0}$ & $\mathbf{1 0 0 \%}$ \\
\hline
\end{tabular}

Sumber: Data Sekunder

Tabel 2. Distribusi jumlah dan persentase karakteristik penderita Tuberculosis Multidrug Resistant (TB MDR) di Sulawesi Tenggara tahun 2014-2017 berdasarkan Jenis Kelamin

\begin{tabular}{ccc}
\hline Jenis Kelamin & Jumlah & Persentase (\%) \\
\hline Laki-laki & 28 & 70 \\
Perempuan & 12 & 30 \\
\hline Total & $\mathbf{4 0}$ & $\mathbf{1 0 0 \%}$
\end{tabular}

Sumber: Data Sekunder

Tabel 3. Distribusi jumlah dan persentase karakteristik penderita Tuberculosis Multidrug Resistant (TB MDR) di Sulawesi Tenggara tahun 2014-2017 berdasarkan pekerjaan

\begin{tabular}{ccc}
\hline Pekerjaan & Jumlah & Persentase (\%) \\
\hline Bekerja: & & \\
Pegawai (PNS) & 4 & 10 \\
Wiraswasta & 11 & 27,5 \\
Petani & 8 & 20 \\
Tidak Bekerja: & & 15 \\
IRT & 6 & 7,5 \\
Pelajar & 3 &
\end{tabular}




\begin{tabular}{ccc} 
Pengangguran & 8 & 20 \\
\hline Total & $\mathbf{4 0}$ & $\mathbf{1 0 0 \%}$
\end{tabular}

Sumber: Data Primer

Berdasarkan Tabel 4, diketahui bahwa penderita Tuberculosis Multidrug Resistant (TB MDR) berdasarkan riwayat pengobatan TB paru paling banyak didapatkan kasus putus berobat berjumlah
25 orang $(62,5 \%)$, kasus kambuh berjumlah 13 orang $(32,5 \%)$, kasus baru berjumlah 2 orang $(5 \%)$, kasus gagal, kasus pindahan dan kasus kronik tidak ditemukan $(0 \%)$.

Tabel 4. Distribusi jumlah dan persentase karakteristik penderita Tuberculosis Multidrug Resistant (TB MDR) di Sulawesi Tenggara tahun 2014-2017 berdasarkan riwayat pengobatan tb paru

\begin{tabular}{ccc}
\hline Riwayat Pengobatan TB Paru & Jumlah & Persentase (\%) \\
\hline Kasus baru & 2 & 5 \\
Kasus kambuh (relaps) & 13 & 32,5 \\
Kasus setelah putus berobat (Default) & 25 & 62,5 \\
Kasus setelah gagal (Failure) & 0 & 0 \\
Kasus Pindahan (Transfer In) & 0 & 0 \\
Kasus lain: kasus kronik & 0 & 0 \\
\hline Total & $\mathbf{4 0}$ & $\mathbf{1 0 0}$ \\
\hline
\end{tabular}

Sumber : Data Sekunder

Berdasarkan Tabel 5, diketahui bahwa pada penderita Tuberculosis Multidrug Resistant (TB MDR) berdasarkan pemeriksaan penunjang TB (foto toraks) didapatkan gambaran foto toraks infiltrat dan kavitas berjumlah 14 orang (35\%), infiltrat dan opasitas berjumlah 7 orang $(17,5 \%)$, infiltrat dan garis fibrosis berjumlah 2 orang (5\%), opasitas dan kavitas berjumlah 2 orang $(5 \%)$, infiltrat berjumlah 6 orang $(15 \%)$, kavitas berjumlah 5 orang $(12,5 \%)$, dan opasitas berjumlah 4 orang $(10 \%)$.

Tabel 5. Distribusi jumlah dan persentase karakteristik penderita Tuberculosis Multidrug Resistant (TB MDR) di Sulawesi Tenggara tahun 2014-2017 berdasarkan pemeriksaan penunjang TB (Foto Toraks)

\begin{tabular}{ccc}
\hline Gambaran Foto toraks & Jumlah & Persentase (\%) \\
\hline Infiltrat dan kavitas & 14 & 35 \\
Infiltrat dan opasitas & 7 & 17,5 \\
Infiltrat dan garis fibrosis & 2 & 5 \\
Opasitas dan kavitas & 2 & 5 \\
Infiltrat & 6 & 15 \\
Kavitas & 5 & 12,5 \\
Opasitas & 4 & 10 \\
\hline Total & $\mathbf{4 0}$ & $\mathbf{1 0 0 \%}$ \\
\hline
\end{tabular}

Sumber : Data Sekunder

Berdasarkan Tabel 6, diketahui bahwa hasil pemeriksaan sputum pada penderita Tuberculosis Multidrug Resistant (TB MDR) terbanyak ditemukan pada BTA $(+1)$ berjumlah 21 orang $(52,5 \%)$. Selanjutnya berturut-turut BTA $(+3)$ berjumlah 10 orang $(25 \%)$, BTA $(+2)$ berjumlah 5 orang $(12,5 \%)$, BTA (-) 
berjumlah 3 orang $(7,5 \%)$ dan BTA (1-9) berjumlah 1 orang $(2,5 \%)$.

Berdasarkan Tabel 7, diketahui bahwa bahwa penderita Tuberculosis Multidrug Resistant (TB MDR) yang resistant rifampisin berjumlah 25 orang $(62,5 \%)$ multidrug resistant berjumlah 15 orang $(37,5 \%)$, dan mono resistant, poli resistant, extensive drug resistant tidak ditemukan $(0 \%)$.

Tabel 6. Distribusi jumlah dan persentase karakteristik penderita Tuberculosis Multidrug Resistant (TB MDR) di Sulawesi Tenggara tahun 2014-2017 berdasarkan pemeriksaan penunjang TB (Pemeriksaan Sputum)

\begin{tabular}{ccc}
\hline Pemeriksaan Sputum BTA & Jumlah & Persentase (\%) \\
\hline+3 & 10 & 25 \\
+2 & 5 & 12,5 \\
+1 & 21 & 52,5 \\
$1-9$ & 1 & 2,5 \\
- & 3 & 7,5 \\
\hline Total & $\mathbf{4 0}$ & $\mathbf{1 0 0 \%}$ \\
\hline
\end{tabular}

Sumber : Data Sekunder

Tabel 7. Distribusi jumlah dan persentase karakteristik penderita Tuberculosis Multidrug Resistant (TB MDR) di Sulawesi Tenggara tahun 2014-2017 berdasarkan jenis resistensi obat

\begin{tabular}{ccc}
\hline Jenis Resistensi Obat & Jumlah & Persentase (\%) \\
\hline Mono resistant (TB MR) & 0 & 0 \\
Poli resistant (TB PR) & 0 & 0 \\
Multi drug resistant (TB MDR) & 15 & 37,5 \\
Extensive drug resistant (TB XDR) & 0 & 0 \\
Resistant Rifampisin (TB RR) & 25 & 62,5 \\
\hline Total & $\mathbf{4 0}$ & $\mathbf{1 0 0}$ \\
\hline
\end{tabular}

Sumber : Data Sekunder

Berdasarkan Tabel 8, diketahui hasil pengobatan pada penderita Tuberculosis Multidrug Resistant (TB MDR) paling banyak masih sementara berobat (on treatment) yaitu berjumlah 28 orang (70\%). Pasien yang meninggal berjumlah 6 orang $(15 \%)$, sembuh berjumlah 5 orang $(12,5 \%)$ dan putus berobat berjumlah 1 orang $(2,5 \%)$.

Tabel 8. Distribusi jumlah dan persentase karakteristik penderita Tuberculosis Multidrug Resistant (TB MDR) di Sulawesi Tenggara tahun 2014-2017 berdasarkan hasil pengobatan

\begin{tabular}{ccc}
\hline Hasil Pengobatan TB MDR & Jumlah & Persentase (\%) \\
\hline On Treatment & 28 & 70 \\
Sembuh & 5 & 12,5 \\
Putus berobat (Default) & 1 & 2,5 \\
Meninggal & 6 & 15 \\
\hline Total & $\mathbf{4 0}$ & $\mathbf{1 0 0 \%}$ \\
\hline
\end{tabular}

Sumber : Data Sekunder

PEMBAHASAN

Karakteristik usia penderita TB MDR

di Sulawesi Tenggara tahun 2014-2017 
Hasil penelitian menunjukkan bahwa kelompok usia terbanyak pada penderita Tuberculosis Multidrug Resistant (TB MDR) adalah pada usia produktif yaitu kelompok usia 15-55 tahun yang berjumlah 34 orang (85\%) dan usia $>56$ tahun berjumlah 6 orang (15\%). Hasil penelitian diatas sejalan dengan penelitian yang dilakukan oleh Linda (2012) di Poli paru Puskesmas Kecamatan Jagakarsa bulan Mei-Juni 2012. Hasil penelitian menunjukan bahwa karakteristik penderita tuberkulosis paru berdasarkan usia, berada pada kelompok usia produktif yaitu 15-55 tahun sebanyak 53 orang $(85,5 \%)$.

Usia adalah satuan waktu yang mengukur waktu keberadaan suatu benda atau makhluk hidup, baik yang hidup maupun yang mati. Pada hasil penelitian ini menunjukan bahwa sebagian besar kejadian TB MDR terjadi pada usia produktif yaitu 15-55 tahun. Usia produktif merupakan usia dengan aktifitas yang tinggi dan terpapar oleh lingkungan.

Berdasarkan data WHO di negara berkembang kasus TB banyak terjadi pada usia produktif, yaitu 15-54 tahun. Usia produktif merupakan usia yang memiliki resiko tinggi terinfeksi TB. Pada jenjang usia ini tingkat penularan pasien TB kepada orang lain sangat tinggi dan mobilitas kerja yang tinggi sehingga penderita cenderung tidak patuh meminum OAT pada pengobatan TB sebelumnya. Seseorang yang sudah mengalami TB pada usia ini, akan mempengaruhi kualitas kerja dilingkungannya dan ketika penderita tidak bekerja maka akan mempengaruhi ekonomisnya (WHO, 2012).

\section{Karakteristik jenis kelamin penderita TB MDR di Sulawesi Tenggara tahun 2014-2017}

Hasil penelitian menunjukan Multidrug Resistant (TB MDR) lebih banyak laki-laki dibandingkan perempuan yaitu jumlah laki-laki sebanyak 28 orang (70\%) dan perempuan berjumlah 12 orang (30\%). Hasil penelitian ini sejalan dengan penelitian Azwar (2017) di RSUD Ulin Banjarmasin periode Desember 2015-Mei 2016 yang menunjukkan jumlah penderita laki-laki 5,3 kali lebih banyak dari pada penderita perempuan yaitu hasil penderita TB MDR berjenis kelamin laki-laki sebanyak 16 orang $(84,2 \%)$, sedangkan perempuan sebanyak 3 orang $(15,8 \%)$.

Jenis kelamin adalah perbedaan antara perempuan dan laki-laki secara biologis sejak seseorang lahir. Pada penelitian ini distribusi penderita TB MDR paling banyak berjenis kelamin laki-laki. Hal ini disebabkan karena secara prevalensi penyakit TB paru lebih banyak menyerang pada laki-laki dari pada perempuan yaitu berdasarkan laporan WHO (2015), bahwa prevalensi TB paru 1,7 kali lebih banyak terjadi pada laki-laki dibanding perempuan. Berdasarkan data dari Dinas kesehatan Provinsi Sulawesi tenggara tahun 2016 bahwa berdasarkan jenis kelamin, rata-rata kasus baru BTA (+) pada laki-laki lebih tinggi dari pada perempuan dengan 59\% berbanding $41 \%$ Secara rata-rata hampir semua kabupaten di Sulawesi Tenggara jumlah penderita laki-laki lebih tinggi.

Penderita TB MDR lebih banyak laki-laki dibanding perempuan disebabkan laki-laki lebih berat beban kerjanya dan sering melakukan banyak kontak dengan lingkungan yang lebih besar diluar rumah dari pada perempuan disamping faktor biologi, sosial budaya. Selain itu laki-laki juga cenderung memiliki gaya hidup yang 
tidak sehat seperti merokok dan minum alkohol (Sarwani, 2012).

Karakteristik pekerjaan penderita TB MDR di Sulawesi Tenggara tahun 20142017

Hasil penelitian menunjukan bahwa pada penderita Tuberculosis Multidrug Resistant (TB MDR) banyak yang bekerja dan paling banyak adalah bekerja sebagai wiraswasta yaitu 11 orang (27,5\%). Hasil penelitian ini sesuai dengan penelitian Munir (2010) di RSUP Persahabatan yaitu pasien TB MDR lebih banyak pekerja swasta yaitu 36 orang $(35,6 \%)$ dan penelitian yang dilakukan oleh Azwar (2017) di RS Ulin Banjarmasin pekerjaan penderita tuberkulosis paru dengan TB MDR terbanyak pada pekerja swasta 6 orang $(31,6 \%)$.

Lingkungan kerja yang buruk mendukung untuk terinfeksi TB paru. Berdasarkan hasil penelitian ini didapatkan penderita lebih banyak yang bekerja sebagai wiraswasta yang apabila dikaitkan dengan penghasilan keluarga, pekerjaan di sektor swasta memiliki penghasilan yang tidak tetap atau dibawah UMR (Upah Minimum Regional), sedangkan pengobatan TB MDR membutuhkan waktu yang lama dan biaya yang mahal. Linda (2012) menyatakan bahwa penghasilan yang rendah akan mempengaruhi pemenuhan kebutuhan sehari-hari termasuk dalam mendapatkan pelayanan kesehatan yang memadai. Tingkat ekonomi yang rendah menjadi hambatan bagi penderita dalam menjangkau fasilitas pelayanan kesehatan. Selain itu, penderita TB membutuhkan nutrisi yang tinggi selama proses penyembuhan.
Karakteristik riwayat pengobatan TB paru penderita TB MDR di Sulawesi Tenggara tahun 2014-2017

Hasil penelitian menunjukan bahwa penderita Tuberculosis Multidrug Resistant (TB MDR) berdasarkan riwayat pengobatan TB paru paling banyak didapatkan kasus putus berobat berjumlah 25 orang $(62,5 \%)$. Putus berobat atau lalai berobat bagi penderita TB adalah penderita yang sudah berobat paling kurang 1 bulan dan berhenti 2 minggu atau lebih, kemudian datang kembali berobat dan umumnya penderita tersebut kembali dengan hasil pemeriksaan dahak BTA positif. Tingginya kasus tuberkulosis paru yang disebabkan oleh ketidakpatuhan terhadap program pengobatan serta rendahnya angka capaian pengobatan yang diakibatkan putus obat menyebabkan pengobatan memakan waktu yang lebih lama dan menyebabkan terjadinya TB MDR (Kemenkes RI, 2011).

Akibat dari putus berobat adalah pasien bisa resisten terhadap obat TB. Resistensi terhadap obat anti tuberkulosis (OAT) terjadi karena adanya mutasi pada gen Mycobacterium tuberculosis. Mutasi ini dapat diinduksi oleh kadar terapeutik obat yang tidak adekuat, terutama akibat ketidakpatuhan selama mengkonsumsi obat. Pengguna OAT yang tidak tepat dan teratur dapat menimbulkan mutasi pada gen yang mengkode target OAT sehingga mutasi pada gen tersebut dapat menyebabkan terjadinya TB MDR (Johnson R, 2006).

Karakteristik pemeriksaan penunjang TB penderita TB MDR di Sulawesi Tenggara tahun 2014-2017 
Hasil penelitian menunjukan bahwa pada penderita Tuberculosis Multidrug Resistant (TB MDR) berdasarkan pemeriksaan penunjang TB (foto toraks) didapatkan gambaran foto toraks terbanyak adalah infiltrat dan kavitas yang berjumlah 14 orang (35\%). Hasil penelitian ini sejalan dengan penelitian yang dilakukan oleh Asmalina (2016) yaitu didapatkan kelainan radiologi foto toraks berupa bentuk bercak berawan (infiltrat) yaitu sebesar 28 orang (90,32\%) disertai dengan gambaran bentuk kavitas dan efusi pleura didapatkan masingmasing sebesar 2 orang $(6,45 \%)$ dan 1 orang $(3,23 \%)$.

Pemeriksaan foto toraks merupakan cara yang praktis dan tidak invasif untuk menemukan lesi tuberkulosis. Sensivitas dan spesifitas foto toraks dalam mendiagnosis TB adalah $86 \%$ dan $83 \%$. Pemeriksaan foto toraks diperlukan untuk mendiagnosis TB paru pasien dengan BTA negatif yang tidak ada perbaikan setelah pemberian obat anti tuberkulosis. Pada pasien dengan sputum BTA positif, foto toraks berperan penting dalam menilai luas lesi serta komplikasi yang terjadi (Majdwati, 2010).

Hasil penelitian menunjukan bahwa hasil pemeriksaan sputum pada penderita Tuberculosis Multidrug Resistant (TB MDR) paling banyak pada BTA $(+1)$ berjumlah 21 orang $(52,5 \%)$, BTA $(+3)$ berjumlah 10 orang $(25 \%)$, BTA $(+2)$ berjumlah 5 orang $(12,5 \%)$, BTA (19) berjumlah 1 orang $(2,5 \%)$ dan BTA (-) berjumlah 3 orang $(7,5 \%)$. Hasil penelitian ini sejalan dengan penelitian yang dilakukan oleh Mulyadi (2011) yaitu didapatkan sampel dengan hasil BTA $(+1)$ Berjumlah 15 orang $(44,1 \%)$, BTA $(+2)$ dan BTA (+3) mempunyai hasil yang sama yaitu masing-masing 7 orang $(20,6 \%)$ dan BTA (-) berjumlah 5 orang $(14,7 \%)$. Sumber penularan TB adalah penderita TB BTA $(+)$. Pasien TB paru BTA positif memberikan kemungkinan risiko penularan TB lebih besar dari pada TB BTA negatif. Tingginya kasus TB BTA (+) perlu diwaspadai agar tidak terjadi penularan penyakit tuberkulosis karena berdasarkan data dari Dinas Kesehatan Provinsi Sulawesi Tenggara tahun 2016, kasus TB BTA (+) di Sulawesi Tenggara banyak ditemukan yaitu 3.105 kasus baru BTA (+) (Profil Dinkes Prov. Sultra, 2016).

Karakteristik jenis resistensi obat penderita TB MDR di Sulawesi Tenggara tahun 2014-2017

Hasil penelitian menunjukan bahwa pada penderita Tuberculosis Multidrug Resistant (TB MDR) jenis resistensi obat yang paling banyak adalah resistant rifampisin (TB RR) yaitu berjumlah 25 orang $(62,5 \%)$, multidrug resistant (TB MDR) berjumlah 15 orang (37,5\%), dan tidak ada jenis resistensi obat mono resistant (TB MR), poli resistant (TB PR), dan extensive drug resistant (TB XDR) (0\%). Berbeda dengan penelitian yang dilakukan oleh Anggia (2016) di RSUD Arifin Achmad Provinsi Riau didapatkan resistensi OAT pasien TB MDR adalah resistensi rifampisin dan isoniazid (TB MDR) sebanyak 9 orang $(50 \%)$.

Selain itu, jenis resistensi OAT yang didapatkan pada penelitian Munir (2010) adalah resistensi rifampisin dan isoniazid (TB MDR) adalah 51 orang (50,5\%). Obat rifampisin dan isoniazid paling banyak didapatkan sebagai jenis resistensi OAT pada pasien TB MDR 
karena rifampisin dan isoniazid merupakan obat lini pertama dalam pengobatan TB sehingga sering digunakan sebagai obat monoterapi dan sering diberikan bersamaan dengan antibiotik lain.

Resistant Rifampisin (TB RR) adalah Mycobacterium tuberculosis yang resistant terhadap Rifampisin dengan atau tanpa resistensi terhadap OAT lain yang terdeteksi menggunakan metode genotip (tes cepat molekuler) atau metode fenotip (konvensional). Pada peneltian ini resistant rifampisin (TB RR) paling banyak ditemukan karena data hasil pemeriksaan gene expert yang terdapat pada rekam medis hanya terdapat resistant rifampisin (TB RR) dan data hasil uji kepekaan obat kurang lengkap (Kemenkes, 2016).

\section{Karakteristik hasil pengobatan penderita TB MDR di Sulawesi Tenggara tahun 2014-2017}

Hasil penelitian menunjukan bahwa hasil pengobatan pada penderita Tuberculosis Multidrug Resistant (TB MDR) paling banyak masih sementara berobat (on treatment) yaitu berjumlah 28 orang $(70 \%)$, pasien meninggal berjumlah 6 orang $(15 \%)$, sembuh berjumlah 5 orang $(12,5 \%)$ dan putus berobat berjumlah 1 orang $(2,5 \%)$. Hasil penelitian ini tidak sejalan dengan penelitian yang dilakukan oleh Munir (2010) di RSUP Persahabatan, yaitu putus obat 32 orang $(31,6 \%)$, gagal 26 orang $(27,9 \%)$, pasien masih dalam pengobatan TB MDR 16 orang $(17,2 \%)$ dan pasien TB MDR yang sembuh didapatkan 2 orang $(2,1 \%)$.

$$
\text { Pada penelitian ini banyak }
$$

diperoleh pasien yang masih sementara berobat, karena tidak diketahui yang masih sementara berobat tetap melanjutkan pengobatannya dengan teratur atau sudah tidak melanjutkan pengobatannya. Hal ini disebabkan karena data hasil pengobatan hanya berdasarkan pada data rekam medis pasien. Putus berobat adalah Pasien kategori IV yang pengobatannya terputus selama berturut-turut dua bulan atau lebih dengan alasan apapun tanpa persetujuan medik. Putus berobat pada penderitaa TB MDR disebabkan karena ketidaktahuan pasien dengan penyakitnya, efek samping obat lini kedua yang lebih berat dari pada lini pertama sehingga pasien tidak ingin meneruskan pengobatannya serta terlalu lama penggunakan obat-obatan menjadi kendala bagi pasien untuk melanjutkan pengobatan (Soepandi, 2010).

Pasien TB MDR dikatakan sembuh apabila pasien yang telah menyelesaikan pengobatan sesuai pedoman pengobatan TB MDR tanpa bukti terdapat kegagalan dan hasil biakan selama tahap lanjutan menunjukan hasil negatif minimal 3 kali berturut-turut dengan jarak pemeriksaan antar biakan minimal 30 hari. Dari hasil ini dapat diketahui bahwa terapi TB MDR memerlukan perhatian khusus karena apabila banyak kasus putus obat dan kasus gagal pada TB MDR dapat berbahaya terhadap perkembangan penyakit di masyarakat (Soepandi, 2010).

\section{SIMPULAN}

Berdasarkan hasil penelitian dan pembahasan dapat disimpulkan bahwa karakteristik penderita Tuberculosis Multidrug Resistant (TB MDR) di Sulawesi Tenggara tahun 2014-2017 adalah terbanyak pada kelompok usia 1555 tahun, jenis kelamin laki-laki, pekerjaan wiraswasta, riwayat kasus putus berobat, pemeriksaan foto toraks berupa gambaran infiltrat dan kavitas, pemeriksaan sputum 
BTA $(+1)$, jenis resistensi Rifampisin, dan masih sementara berobat.

\section{SARAN}

Perlu diperhatikan dan dijaga dengan baik kelengkapan seluruh rekam medik pasien TB MDR untuk memudahkan penelitian dalam mengumpulkan data pasien, perlu dilakukan penelitian lebih lanjut hubungan beberapa karakteristik TB MDR untuk menjelaskan hubungan masing-masing variabel, peran PMO perlu ditingkatkan dalam mengawasi keteraturan berobat penderita TB MDR dan diharapkan pemerintah lebih meningkatkan sosialisasi yang intensif tentang TB MDR di kota/kabupaten pada provinsi Sulawesi Tenggara, sehingga penemuan kasus dan penanganan TB MDR di daerah-daerah menjadi lebih baik dan dapat mencegah terjadinya penularan TB MDR.

\section{DAFTAR PUSTAKA}

Anggia VP, Indra PY, Fauzia D.2015. Profil Pasien Tuberculosis Multidrug Resistance (TB- MDR) di Poliklinik TB MDR RSUD Arifin Achmad Provinsi Riau Periode April 2013-Juni 2014. JOM FK 1(2)

Asmalina. 2016. Kejadian Tuberkulosis Resisten Primer pada Fasilitas Pelayanan Kesehatan. $J$ Respir Indo 36(2)

Azwar, GA., Noviana,DI., Hendriyono, FX. 2017. Karakteristik Penderita Tuberkulosis Paru Dengan Multidrug Resistant Tuberculosis (Mdr-Tb) di Rsud Ulin Banjarmasin. Berkala Kedokteran 13(1) : 23-32

Dinas Kesehatan Provinsi Sulawesi Tenggara. 2016 . Profil Kesehatan Provinsi Sulawesi
Tenggara Tahun 2015. Dinkes Prov. Sultra. Kendari

Johnson R. 2006. Drug resistance in Mycobacterium tuberculosis. Curr Issues Mol Biol 8:97-111.

Kementrian Kesehatan RI. 2011. Strategi Nasional Pengendalian TB di Indonesia $2010 \quad 2014$. Pengendalian Penyakit dan Penyehatan Lingkungan. Jakarta

Kementrian Kesehatan RI. 2014. Pedoman Nasional Pengendalian Tuberkulosis. Pengendalian Penyakit dan Penyehatan Lingkungan. Jakarta

Kementrian Kesehatan RI. 2016. Tuberkulosis Temukan Obati Sampai Sembuh. Pencegahan Pengendalian Penyakit. Jakarta

Linda. 2012. Hubungan Karakteristik Klien Tuberkulosis dengan Pengetahuan tentang Multidrug Resisten Tuberkulosis (MDR TB) di Poli Paru Puskesmas Kecamatan Jagakarsa. Skripsi. Fakultas Ilmu Keperawatan Depok.

Mulyadi, Mudatsir, Nurlina. 2011. Hubungan Tingkat Kepositifan Pemeriksaan Basil Tahan Asam (BTA) dengan Gambaran Luas Lesi Radiologi Toraks pada Penderita Tuberkulosis Paru yang Dirawat Di SMF Pulmonologi RSUDZA Banda Aceh. J Respir Indo 31(3): 133-137

Munir SM, Nawas A, Soetoyo DK. 2010. Pengamatan pasien tuberkulosis paru dengan multidrug-resistant (TB-MDR) di Poliklinik Paru RSUP Persahabatan. $J$ Respir Indo 30(2): 92-105.

Sarwani. 2012. Faktor Risiko Multidrug Resistant Tuberculosis (MDRTB). Jurnal Kesehatan Masyarakat 8(1): 60-66 
Sihombing, dkk. 2012. Pola Resistensi Primer pada Penderita TB paru Kategori 1 di RSUP H. Adam Malik Medan. J Respir Indo 32(3)

Soepandi, Priyanti Z. 2010. Diagnosis dan Faktor yangMempengaruhi Terjadinya TB-MDR. PPTI 7: 497-501
WHO. 2012. Global Tuberculosis Control 2012. Geneva.

WHO. 2015. Global Tuberculosis Report 2015. Geneva.

WHO. 2016. Bending The Curve Ending $T B$. World Health Organization Regional Office for South-east Asia 